\title{
Biosorption of Trivalent Chromium from Aqueous Solution by Red Seaweed Polysiphonia nigrescens
}

\author{
Patricia Blanes $^{1}$, Luis Sala ${ }^{1 *}$, Silvia García ${ }^{1}$, Juan González ${ }^{1}$, María Frascaroli ${ }^{1}$, \\ Masafumi Harada ${ }^{2}$, Cong Cong ${ }^{3}$, Yasuhiro Niwa ${ }^{3}$, Cristina Matulewicz ${ }^{4}$, \\ Héctor Prado ${ }^{4}$, Adriana Cortadi ${ }^{5}$, Martha Gattuso ${ }^{5}$ \\ ${ }^{1}$ National University of Rosario, Rosario, Argentina \\ ${ }^{2}$ Faculty of Human Life and Environment, Nara Women's University, Nara, Japan \\ ${ }^{3}$ Photon Factory, High Energy Accelerator Research Organization (KEK), Tsukuba, Japan \\ ${ }^{4}$ Faculty of Exact and Natural Sciences, University of Buenos Aires, Buenos Aires, Argentina \\ ${ }^{5}$ Faculty of Biochemical and Pharmaceutical Sciences, National University of Rosario, Rosario, Argentina \\ E-mail:"sala@iquir-conicet.gov.ar,garcia@iquir-conicet.gov.ar \\ Received September 9, 2011; revised October 5, 2011; accepted November 4, 2011
}

\begin{abstract}
This paper presents the biosorption of chromium onto red seaweed (Polysiphonia nigrescens). Batch mode experiments were performed to determine experimental parameters affecting sorption process such as $\mathrm{pH}$, contact time, initial metal ion concentration and biomass dosage. $\mathrm{The} \mathrm{Cr}(\mathrm{III})$ sorption was dependent on $\mathrm{pH}$ and adsorbent dosage. The adsorption kinetic data could be fitted with a pseudo-second-order model and the equilibrium data with a Langmuir model. The maximum sorption capacity was of $16.11 \mathrm{mg} / \mathrm{g}$ at $\mathrm{pH} 4$ and 10 $\mathrm{g} / \mathrm{L}$ of biomass dosage. $0.1 \mathrm{M} \mathrm{H}_{2} \mathrm{SO}_{4}$ showed good desorption efficiency $(>80 \%)$. Spectroscopy analysis showed that $\mathrm{Cr}(\mathrm{III})$ sorption on seaweed was mainly through the ion-exchange mechanism. This report indicates that $P$. nigrescens is an effective and economical sorbent for removal of $\mathrm{Cr}(\mathrm{III})$ from wastewaters.
\end{abstract}

Keywords: Seaweed Polysiphonia nigrescens, Biosorption, Chromium, Isotherms, Kinetics Parameters

\section{Introduction}

Pollution of surface and groundwater supplies with toxic heavy metal has been one of the major causes for the deterioration in water quality. Non-treated effluents from industries such as metallurgical, electronic, tannery, electro-plating, among others contain high level of chromium, and other heavy metals $[1,2]$. In many countries the heavy metal content in drinking waters and wastewaters often exceed the permissible standards. According to the United States Environmental Protection Agency the discharge of $\mathrm{Cr}(\mathrm{VI})$ to surface water is regulated to $<0.05 \mathrm{mg} / \mathrm{L}$, whereas the total chromium (containing $\mathrm{Cr}(\mathrm{III}), \mathrm{Cr}(\mathrm{VI})$, and other forms of chromium) is regulated to be discharged at $<2 \mathrm{mg} / \mathrm{L}$ [3].

Several methods have been applied over the years on the elimination of chromium present in industrial wastewaters and soils $[1,2,4-6]$. However, technical or economic factors limit sometimes the feasibility of such processes. Biosorption is a cost effective process by using biomass raw materials which are either abundant (seaweeds) or wastes from other industrial operations (fermentation or seaweed processing wastes) for decontamination of ionic pollutants, such as heavy metal ions [7]. Different species of algae biomasses have been used for the removal of heavy metals from aqueous solution [2,4-10]. Biosorption in brown and green algae has mainly been attributed to the presence of alginate in their cell wall; containing functional groups such as carboxylic acid (guluronic and mannuronic acids) which can act as binding sites for metals via both electrostatic attraction and complexation. The red algae are characterized by the presence of polysaccharides like carrageenan that recovers a number of different linear sulfated galactans [8]. Prado et al. [11] explained that high level of sulfation of the polysaccharides from $P$. nigrescens suggests that this seaweed could constitute an important biomass for removing heavy metals from aqueous environments. However, according to authors' survey, there is no extensive study on the sorption of $\mathrm{Cr}(\mathrm{III})$ using $P$. nigrescens in literature.

The present work focused on the investigation of po- 
tential of $P$. nigrescens biomass for removal of $\mathrm{Cr}$ (III) ions from aqueous solution. Experimental parameters affecting the sorption process such as $\mathrm{pH}$, contact time, initial metal ion concentration and biomass dosage were studied. The equilibrium sorption data were evaluated by two parameter models, namely Langmuir, Freundlich, Dubinin-Radushkevich (D-R), and three parameter models, namely Redlich-Peterson, Sips and Toth isotherm models. The experimental results were also analyzed in terms of kinetics approach. The functional groups involved in metal sorption were examined using Fourier transform infrared spectroscopy (FT-IR). The morphological changes of $P$. nigrescens before and after metals sorption were explored by microscopy techniques like scanning electron micrographs-energy dispersive $\mathrm{X}$-ray analysis (SEM-EDX). The metal ion interaction with seaweed was examined using X-ray absorption spectroscopy (XAS) analysis. Finally, desorption studies were made using dilute desorbing agent.

\section{Experimental}

\subsection{Materials}

P. nigrescens was collected in Cabo Corrientes $\left(38^{\circ} 03^{\prime} \mathrm{S}\right.$, $57^{\circ} 31^{\prime} \mathrm{W}$, Mar del Plata, Argentina). Biomass was washed several times using de-ionized water to remove extraneous and salts. They were then dried at $40^{\circ} \mathrm{C}$ for $24 \mathrm{~h}$. The dried algae biomass was chopped, sieved and the particles with an average size of $0.5 \mathrm{~mm}$ were used for sorption experiments.

Standard stock solutions of chromium containing 1000 $\mathrm{mg} / \mathrm{L}, \mathrm{Cr}(\mathrm{III})$ as $\mathrm{Cr}\left(\mathrm{NO}_{3}\right)_{3} .9 \mathrm{H}_{2} \mathrm{O}$ and $\mathrm{Cr}_{2} \mathrm{O}_{3}$ were purchased from Sigma-Aldrich (Germany). Working solutions $(250 \mathrm{mg} / \mathrm{L})$ were prepared by dilution of the stock with distilled water. Adjustment of solution $\mathrm{pH}$ to the desired value was achieved using $0.1 \mathrm{M} \mathrm{NaOH}$ and $\mathrm{HCl}$. The reference solid compounds for XAS studies were $\mathrm{Cr}\left(\mathrm{NO}_{3}\right)_{3} \cdot 9 \mathrm{H}_{2} \mathrm{O}$ and $\mathrm{Cr}_{2} \mathrm{O}_{3}$.

\subsection{Chromium Analysis}

Total Cr(III) concentration was determined by spectrophotometry UV-Visible at $540 \mathrm{~nm}$ as the $\mathrm{Cr}$ (III) difenilcarbazone complexe, by using a double-beam UV-Vis JASCO V-550 spectrophotometer after oxidizing Cr(III) to $\mathrm{Cr}(\mathrm{VI})$ prior to the 1,5-diphenylcarbazide (DPC) reaction. The amount of $\mathrm{Cr}$ sorbed per unit sorbent (mg of metal ions/g of dry sorbent) was calculated from the difference between the initial chromium concentration of the control solutions and the final total $\mathrm{Cr}$ concentration in the respective supernatant solutions. Concentrations were determined with an analytical error $<3 \%$ estimated from the triplicated analysis of the standard stock solutions [4].

\subsection{Batch Sorption Experiments}

The sorption of total chromium on the P. nigrescens was investigated in batch biosorption experiments performed at room temperature $\left(25^{\circ} \mathrm{C} \pm 2{ }^{\circ} \mathrm{C}\right)$. The effect of $\mathrm{pH}$ on the sorption capacity was investigated as follows: $10 \mathrm{~g} / \mathrm{L}$ of algae was mixed with $100 \mathrm{mg} / \mathrm{L} \mathrm{Cr}$ (III) for $180 \mathrm{~min}$, in the $\mathrm{pH}$ range of $1-5.5$, which was adjusted with $0.1 \mathrm{M}$ $\mathrm{HCl}$ or $0.1 \mathrm{M} \mathrm{NaOH}$ at the beginning of the experiment. The effect of biomass dosage on the sorption of chromium was studied using different biomass dosage in the range 7 - $67 \mathrm{~g} / \mathrm{L}$ mixed with $100 \mathrm{mg} / \mathrm{L} \mathrm{Cr}$ (III) for 180 $\mathrm{min}$ at $\mathrm{pH}$ 4. Optimization of contact time for $\mathrm{Cr}(\mathrm{III})$, $100 \mathrm{mg} / \mathrm{L}$ of metal solution with a $10 \mathrm{~g} / \mathrm{L}$ dosage of the sorbent at pH 4 was shaked on an orbital shaker at 200 rpm. Samples were collected at definite intervals time in the range 5 - $180 \mathrm{~min}$. The effect of initial metal ion concentration on the sorption capacity was investigated as follows: $10 \mathrm{~g} / \mathrm{L}$ of algae was mixed with a varying amount of $\mathrm{Cr}$ (III) in the range $3-1500 \mathrm{mg} / \mathrm{L}$ during 180 $\min$ at $\mathrm{pH} 4$. The metal solutions were filtered after the desired contact time and a $\mathrm{Cr}$ ion concentration in the filtrate was determined.

Sorption isotherms were performed at $\mathrm{pH} 4$ and the sorbent dosage was $10 \mathrm{~g} / \mathrm{L}$. The metal concentration was varied between 3 and $1200 \mathrm{mg} / \mathrm{L}$. The suspension was maintained under agitation for $3 \mathrm{~h}$ using an orbital shaker at room temperature. Finally, the residual concentration of metal ion was analyzed. Two and three-parameter isotherm models were used to explain the equilibrium data. The sorption equation parameters and thermodynamics assumptions of these equilibrium models help to understand the sorption mechanism and surface properties along with affinity of the sorbent.

\subsection{SEM-EDX Analysis}

The surface structure of sorbent before and after sorption of chromium was analyzed by scanning electron microscope coupled with energy dispersive X-ray analysis (SEMEDX). Leitz AMR 1000 equipped with silica/lithium dispersive detector of X-ray at 200x magnification coupling to analyze and computer EDX.

\subsection{FT-IR Analysis}

The native seaweeds before and after sorption of $\mathrm{Cr}$ (III) were recorded with a Perkin Elmer FT-IR Spectrum One spectrometer. $5.0 \mathrm{mg}$ of dried biomass ( $P$. nigrescens) was mixed and ground with $150 \mathrm{mg}$ of $\mathrm{KBr}$ in an agate 
mortar. The translucent disks were prepared by pressing the ground material bench press. The tablets were immediately analyzed with a spectrometer in the scanning between 3600 and $400 \mathrm{~cm}^{-1}$, whit 10 scans and spectral resolution $4 \mathrm{~cm}^{-1}$ in the transmittance mode obtained the FT-IR spectra.

\subsection{XAS Analysis}

XAS experiments at the Cr K-edge (5989 eV) were carried out at beamline BL-9A with ring energy of $2.5 \mathrm{GeV}$ and a ring current of $450 \mathrm{~mA}$. A double-crystal Si(111) monochromator was used, and the beam was focused using a pair of bent conical mirrors coated with $\mathrm{Rh}$ [4]. The XAFS spectra of Cr-laden seaweed samples were recorded in transmission mode, with $\mathrm{N}_{2}(30)-\mathrm{He}(70)$ gas for the $\mathrm{I}_{0}$ chamber and $\mathrm{N}_{2}$ gas for the I chamber to monitor the incident and transmitted X-rays, respectively. The XANES spectra were measured with $0.35 \mathrm{eV}$ steps and 1 s collecting time between 5980 and $6060 \mathrm{eV}$, while the EXAFS spectra were measured with $2.5 \mathrm{eV}$ steps and $4 \mathrm{~s}$ in transmission mode collecting time between 5500 and $7080 \mathrm{eV}$. The reference samples were used to compare their spectral shapes and to identify major $\mathrm{Cr}$ species on the biomaterial surface [4].

\subsection{Desorption Experiments}

Sorbents were exposed to $10 \mathrm{mg} / \mathrm{L}$ of $\mathrm{Cr}(\mathrm{III})$ at $\mathrm{pH} 4$. Mixtures were stirred for $180 \mathrm{~min}$ to reach equilibrium and then centrifuged. The supernatants were analyzed for their $\mathrm{Cr}$ content. After that, chromium-loaded sorbents were filtered and slightly rinsed with de-ionized water (at $\mathrm{pH} 4$ ) to remove the excess of chromium solution. Then the sorbent was added to $30 \mathrm{~mL}$ of $0.1 \mathrm{M} \mathrm{H}_{2} \mathrm{SO}_{4}, 0.1 \mathrm{M}$ $\mathrm{HCl}, 0.1 \mathrm{M} \mathrm{Na}_{2} \mathrm{CO}_{3}$ or $0.1 \mathrm{M} \mathrm{CaCl}_{2}$ solutions. A desorption agent was mixed with the residue and equilibrated for $2 \mathrm{~h}$, the resulting mixture was filtered and the filtrate analyzed for $\mathrm{Cr}$ (III) concentration. Regenerated sorbents were rinsed with de-ionized water, dried at $40^{\circ} \mathrm{C}$ for $24 \mathrm{~h}$, and weighed to obtain the mass lost after the regeneration step.

\section{Results and Discussion}

\subsection{SEM-EDX Analysis}

The SEM images for $P$. nigrescens before metal sorption (Figure 1(a)) show that contains fold structures a rough appearance. After $\mathrm{Cr}$ (III) binding, the surface of seaweed appears flattened in comparison to the raw sample which indicates some rearrangement of surface polymer (Figure 1(b)).

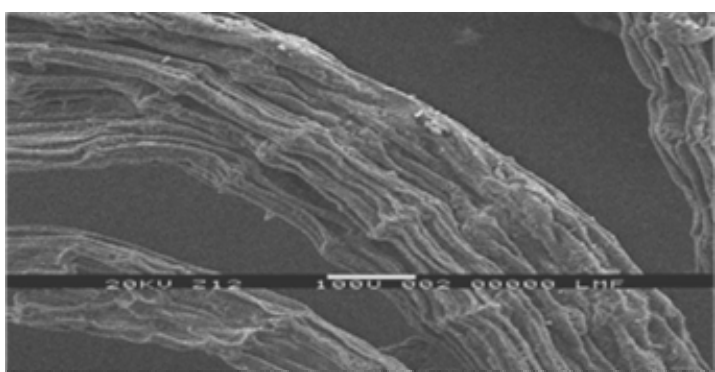

(a)

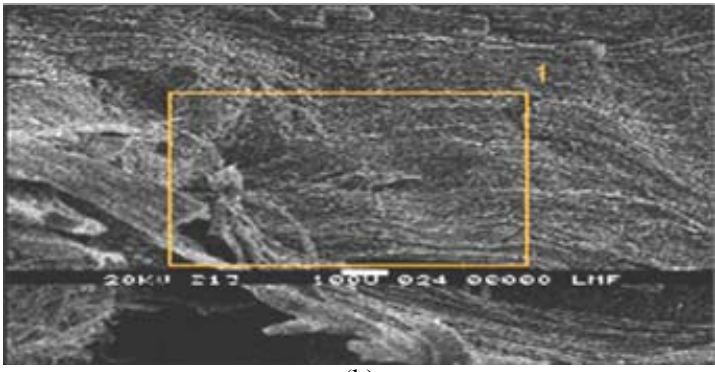

(b)

Figure 1. SEM spectra of $P$. nigrescens, (a) raw seaweed, (b) Cr(III)-loaded seaweeds.

Yang and Chen [12] reported that, for Cr(VI) binding to Sargassum sp., changes in surface morphology were due to an exchange of the desired metal with alkali metals causing relaxation of the biomass structures thus leading to an apparent flattening of the biomass surface. Sorption of $\mathrm{Cr}$ (III) on the surface of the sorbent was confirmed from the elemental analysis by EDX method. As this technique has been used only qualitatively and the scale used for the EDX spectra is arbitrary, it is difficult to evaluate changes in peak size or intensity.

\subsection{FT-IR Analysis}

The FT-IR spectra of unloaded biomass and $\mathrm{Cr}$ (III)loaded biomass were taken to obtain information on the nature of possible interactions between the functional groups of $P$. nigrescens and the metal ions and are listed in Table 1. In the seaweed before sorption, the broad band at $3409 \mathrm{~cm}^{-1}$ may be due to the overlapping of $\mathrm{O}-\mathrm{H}$ and N-H stretching vibration. The band at $2921 \mathrm{~cm}^{-1}$ is assigned to the $-\mathrm{CH}$ stretch. A strong asymmetric $\mathrm{C}=\mathrm{O}$ stretch initially present at $1653 \mathrm{~cm}^{-1}$ in unloaded biomass was shifted to $1646 \mathrm{~cm}^{-1}$ after $\mathrm{Cr}$ (III) sorption, thus pointing to changes in carboxyl symmetry after chromium binding. The bands peaks at $1449 \mathrm{~cm}^{-1}$ may be attributed to symmetric stretching vibration of $\mathrm{C}=\mathrm{O}$ groups and was shifted to $1447 \mathrm{~cm}^{-1}$ after $\mathrm{Cr}$ (III) sorption. This decrease, coupled whit a peak increase of the $\mathrm{C}-\mathrm{O}$ stretch from 1230 to $1250 \mathrm{~cm}^{-1}$ after binding pointed to coordination between seaweed carboxyl groups and chromium 
ions [5]. The bands at $1230 \mathrm{~cm}^{-1}$; that represent $-\mathrm{SO}_{3}$ asymmetric stretching appear in the spectrum at 1250 $\mathrm{cm}^{-1}$ after metal binding. The band at $1153 \mathrm{~cm}^{-1}$ assigned to the symmetric $-\mathrm{SO}_{3}$ was shifted to $1158 \mathrm{~cm}^{-1}$ after Cr(III) sorption. This could implicate that these groups, mainly present in sulfonic acids of polysaccharides, such as agaran, were involved in metal complexation by $P$. nigrescens. Before $\mathrm{Cr}$ (III) sorption, the band -CO stretching of alcoholic groups was assigned at $1078 \mathrm{~cm}^{-1}$ and was shifted to $1066 \mathrm{~cm}^{-1}$.

This could implicate that biomass hydroxyl groups also played a major role in chromium binding. The functional groups suggested here agree with those reported in other studies on FT-IR of seaweed $[2,5,10]$.

\subsection{XAS Analysis}

X-ray Absorption Near-Edge Structure (XANES) is a technique used to determine oxidation state, coordination geometry, and the nature of the bond between the absorbing atom and its ligands. The XANES spectra of $\mathrm{Cr}_{2} \mathrm{O}_{3}$ and $\mathrm{Cr}\left(\mathrm{NO}_{3}\right)_{3} \cdot 9 \mathrm{H}_{2} \mathrm{O}$ were used as references for the know oxidation state and chemical species of $\mathrm{Cr}$. Figure 2 shows the normalized $\mathrm{Cr} \mathrm{K}$-edge XANES spectra of reference compounds and Cr-loaded biomass. The XANES data for Cr(III) standards show a small peak at $5990.5 \mathrm{eV}$. The XANES spectra of the reference compounds containing $\mathrm{Cr}$ (III) show that even though $\mathrm{Cr}$ in these compounds is in the trivalent oxidation state, the corresponding spectral features in XANES are sensitive to changes in the bonding geometry of the $\mathrm{Cr}$ atom. The distinct features can therefore be applied to determine the bonding environment of $\mathrm{Cr}$ (III) bound to biomaterial. The octahedral symmetry in XANES spectra of $\mathrm{Cr}$ (III) compounds is characterized by small resonances in the pre-edge region assigned to transitions of $1 \mathrm{~s}$ electrons into antibonding orbitals with octahedral symmetry whereas $\mathrm{Cr}(0)$ (body centered cubic) shows a broad pre-edge conduction band feature [4].

On the other hand, $\mathrm{Cr}$ (III)-laden seaweed have a small peak at $5990.5 \mathrm{eV}$, indicating the presence of $\mathrm{Cr}$ (III) binding in biomaterial. EXAFS spectroscopy was employed to determine the local atomic structure of $\mathrm{Cr}$ in $\mathrm{Cr}$ (III)-laden seaweed. The curve-fitted values are given in Table 2. For $\mathrm{Cr}\left(\mathrm{NO}_{3}\right)_{3} \cdot 9 \mathrm{H}_{2} \mathrm{O}$, the $k^{3}$-weighted FT function gave a main peak centered at $1.60 \AA$ which arises from first-shell oxygen back-scattering and another smaller peak centered at $\sim 3.15 \AA$ (phase- uncorrected). Three main peaks at $1.60,2.52$, and $3.31 \AA$ (phase-uncorrected) could also be observed for the $\mathrm{Cr}_{2} \mathrm{O}_{3}$ compound, assigned to the first, second, and third shell contributions of a $\mathrm{Cr}(\mathrm{III})$ in an octahedral symmetry, respectively.
Table 1. The FT-IR spectral characteristics of seaweed before and after sorption.

\begin{tabular}{|c|c|c|}
\hline \multicolumn{2}{|c|}{ Sorption band (1/cm) } & \multirow{2}{*}{ Assignment } \\
\hline Before sorption & After sorption & \\
\hline 3409 & 3419 & -OH and $-\mathrm{NH}$ stretching \\
\hline 2921 & 2922 & $\begin{array}{l}-\mathrm{CH} \text { asymmetric stretch of } \\
\text { aliphatic chains }\end{array}$ \\
\hline 2855 & 2855 & $\begin{array}{l}-\mathrm{CH} \text { symmetric stretch of } \\
\text { aliphatic chains }\end{array}$ \\
\hline 1653 & 1646 & $\mathrm{C}=\mathrm{O}$ asymmetric stretching \\
\hline 1540 & 1539 & $-\mathrm{NH}$ amine bends \\
\hline 1449 & 1447 & $\mathrm{C}=\mathrm{O}$ symmetric stretching \\
\hline 1230 & 1250 & $-\mathrm{SO}_{3}$ asymmetric stretching \\
\hline 1153 & 1158 & $-\mathrm{SO}_{3}$ symmetric stretching \\
\hline 1078 & 1066 & $\begin{array}{l}\text {-CO stretching of alcoholic } \\
\text { groups }\end{array}$ \\
\hline
\end{tabular}

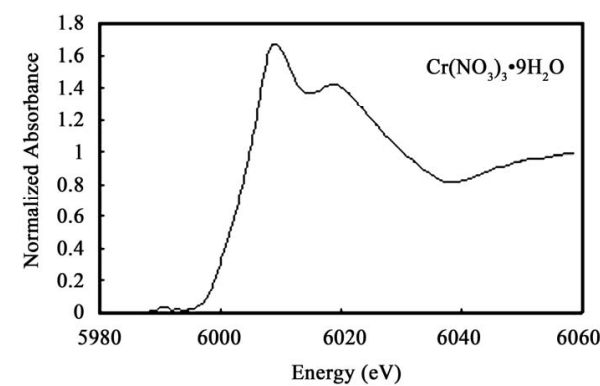

(a)

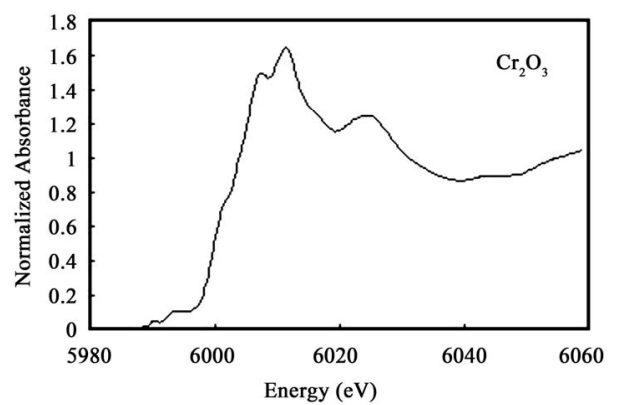

(b)

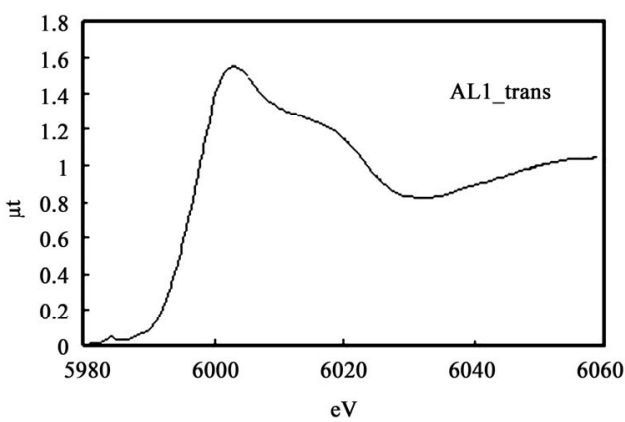

(c)

Figure 2. Cr K-edge XANES spectra of solid samples of (a) $\mathrm{Cr}\left(\mathrm{NO}_{3}\right)_{3} \cdot 9 \mathrm{H}_{2} \mathrm{O}$, (b) $\mathrm{Cr}_{2} \mathrm{O}_{3}$, and (c) $\mathrm{Cr}$ (III)-laden seaweed. 
Table 2. Cr K-edge EXAFS fitting results for reference samples and Cr-laden biomaterial.

\begin{tabular}{ccccccc}
\hline Sample & Bond & $\mathbf{C N}$ & $\boldsymbol{r}(\AA)$ & $\boldsymbol{\Delta E}(\mathbf{e V})$ & $\boldsymbol{\sigma}(\AA)$ & $\boldsymbol{R}(\mathbf{\%})$ \\
\hline $\mathrm{Cr}_{2} \mathrm{O}_{3}$ & $\mathrm{Cr}-\mathrm{O}$ & 4.9 & 1.99 & 4.75 & 0.061 & 2.51 \\
$\mathrm{Cr}\left(\mathrm{NO}_{3}\right)_{3} \cdot 9 \mathrm{H}_{2} \mathrm{O}$ & $\mathrm{Cr}-\mathrm{O}$ & 5.2 & 1.98 & 4.73 & 0.058 & 3.03 \\
Algae-Cr(III) & $\mathrm{Cr}-\mathrm{O}$ & 5.2 & 1.99 & 3.84 & 0.069 & 4.61 \\
\hline
\end{tabular}

The error bar of $r$ and $\mathrm{CN}$ were estimated by varying the $\Delta E$ value $( \pm 10 \mathrm{eV})$ and the $\sigma$ value $( \pm 0.01 \AA)$, respectively. The estimated error bars in the $r$ and $\mathrm{CN}$ values are $\pm 0.02 \AA$ and $\pm 10 \%$, respectively.

This result means that the coordination environment of the chromium on the biomaterial was also similar to that of $\mathrm{Cr}(\mathrm{III})$ compound, where $\mathrm{Cr}(\mathrm{III})$ is in an octahedral geometrical arrangement. The $\mathrm{Cr}-\mathrm{O}$ bond distances were approximately the same lengths, which corresponds to the $\mathrm{Cr}-\mathrm{O}$ bond lengths cited in the literature $[4,13,14]$. For the curve-fitting to determine the structural parameters, phase and amplitude functions for the absorbing and back - scatterer $(\mathrm{Cr}, \mathrm{O})$ pair were extracted from the filtering of the first peak of the EXAFS Fourier transform of $\mathrm{Cr}\left(\mathrm{NO}_{3}\right)_{3} \cdot 9 \mathrm{H}_{2} \mathrm{O}$, where the chromium absorbing atom is surrounded by 6 oxygen atoms at the bond distance of $1.98 \AA[13,14]$.

\subsection{Effect of $\mathrm{pH}$}

Solution $\mathrm{pH}$ is an important parameter that controls sorption process, because of the ionization of surface functional groups and the alteration of the solution composition. The relationship between chromium uptake and solution $\mathrm{pH}$ is illustrated in Figure 3.

The uptake of $\mathrm{Cr}(\mathrm{III})$ increased significantly as the value of $\mathrm{pH}$ increased from 1 to 4 . The sorption capacity of $\mathrm{Cr}(\mathrm{III})$ at $\mathrm{pH} 3.5$ by the seaweed was $6.0 \mathrm{mg} / \mathrm{g}$, which came down to $5.4 \mathrm{mg} / \mathrm{g}$ at $\mathrm{pH} 5.5$. No further increase in the $\mathrm{Cr}(\mathrm{III})$ was observed after $\mathrm{pH} 4$.

At low $\mathrm{pH}$ the positively charged hydrogen ions may compete with metal ions for binding ligands on the cell wall and this leads to fewer sites being available to bind metal ions. However; $29 \%$ of $\mathrm{Cr}$ (III) in solution was adsorbed at $\mathrm{pH} 1$ and this may be due to the presence of sulphonate groups that are dissociated at this $\mathrm{pH}$. An increase in the sorption of $\mathrm{Cr}(\mathrm{III})$ at $61 \%$ with the increase of $\mathrm{pH}$ can be explained on the basis of decrease in competition between protons and metal cations for the same functional groups. At pH 3.5 - 5 carboxyl groups on the seaweed generate a negatively charged surface and electrostatic interactions between cationic species and this surface can be responsible for metal biosorption $[1,5,10]$. A declining sorption trend was observed when the $\mathrm{pH}$ was increased to 5.5. This may be attributed to the decreased solubility of $\mathrm{Cr}(\mathrm{III})$ at high $\mathrm{pH}$ [15]. For this reason, sorption was not investigated at $\mathrm{pH}$ above 5.5.

\subsection{Effect of Biomass Dosage}

The effect of sorbent dose on the sorption of $\mathrm{Cr}$ (III) ions was studied in the range, $7-67 \mathrm{~g} / \mathrm{L}$. Figure 4 shows that the sorption capacity of metal ions is inversely proportional to sorbent dose, when the initial concentration of $\mathrm{Cr}$ (III) is kept constant at $100 \mathrm{mg} / \mathrm{L}$, and tends to a constant value for biomass dosage over $50 \mathrm{~g} / \mathrm{L}$. The sorption capacity decreased from 5.8 to $0.9 \mathrm{mg} / \mathrm{g}$ when seaweed dosage was increased from 7 to $67 \mathrm{mg} / \mathrm{L}$. Garg et al. [16] explain that sorption capacity decrease with increase in sorbent dose due to overlapping of adsorption sites as a result of overcrowding of adsorbent particles. This observation has also been reported by other authors $[4,10$, 17].

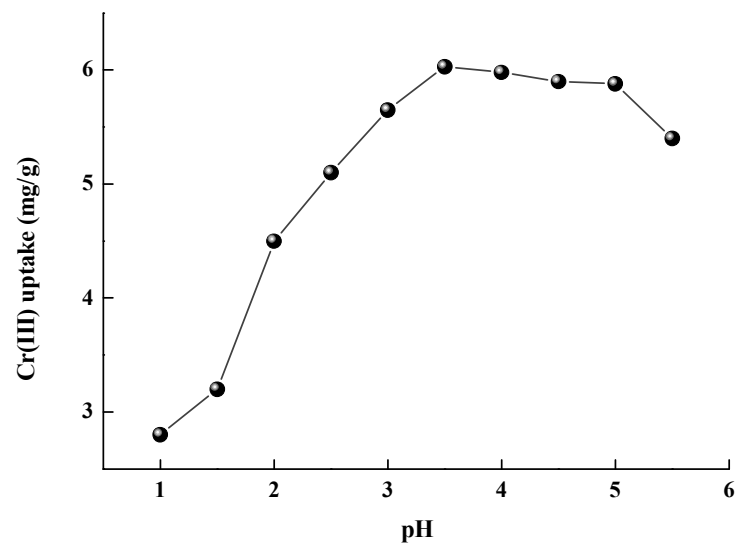

Figure 3. Determination of optimum pH for $\mathrm{Cr}$ (III) sorption. Conditions: $\mathrm{T}=25^{\circ} \mathrm{C},[\mathrm{Cr}(\mathrm{III})]_{\mathrm{i}}=100 \mathrm{mg} / \mathrm{L}$, biomass dose $=10 \mathrm{~g} / \mathrm{L}$.

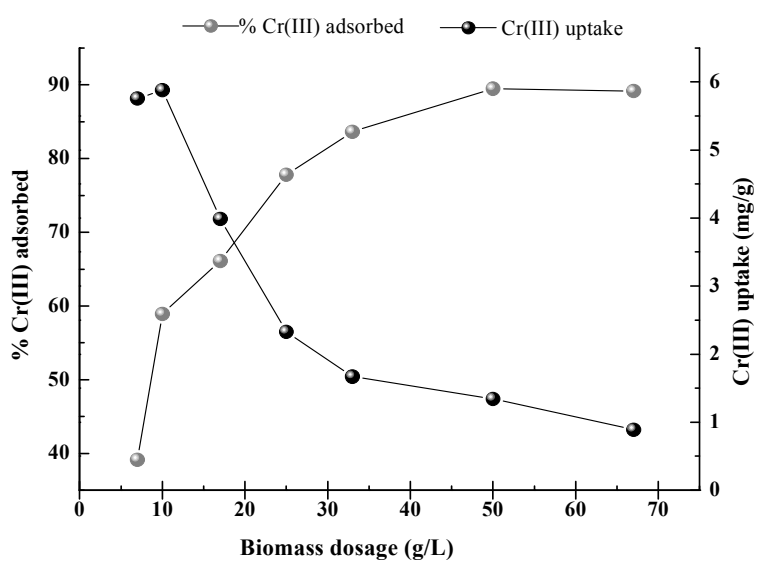

Figure 4. Determination of optimum biomass dosage for Cr(III) sorption. Conditions: $\mathrm{T}=25^{\circ} \mathrm{C},[\mathrm{Cr}(\mathrm{III})]_{\mathrm{i}}=100$ $\mathrm{mg} / \mathrm{L}, \mathrm{pH}=4$. 
On the other hand, in terms of removal efficiency, \% removal of the metal increased from $39 \%$ to $89 \%$ with an increase in the sorbent dose from 7 to $67 \mathrm{mg} / \mathrm{L}$. This is expected because the higher dose of sorbent in the solution, the greater adsorbent surface area and availability of more adsorption sites $[10,16,17]$. Therefore, the optimum biomass dosage was selected as $10 \mathrm{~g} / \mathrm{L}$ for further experiments.

\subsection{Effect of Initial Concentration of $\mathrm{Cr}$ (III)}

The initial concentration provides an important driving force to overcome all mass transfer resistance of $\mathrm{Cr}(\mathrm{III})$ between the aqueous and solid phases resulting in higher probability of collision between the adsorbates with adsorbents $[2,4]$. It can be seen from Figure 5 that when the initial $\mathrm{Cr}$ (III) concentration increased from 3 to 1500 $\mathrm{mg} / \mathrm{L}, \mathrm{Cr}(\mathrm{III})$ removal decrease from $50.5 \%$ to $8.8 \%$ and $\mathrm{Cr}$ (III) uptake capacity of the biomass increased from 0.15 to $13.8 \mathrm{mg} / \mathrm{g}$. It was noted that, as the initial concentration increased the sorption of $\mathrm{Cr}$ (III) increased as is generally expected due to equilibrium process. But $\mathrm{Cr}$ concentration above $800 \mathrm{mg} / \mathrm{L}$ did not increase the sorption significantly and remained almost constant indicating saturation of all the binding sites on sorbent surface beyond a particular concentration.

\subsection{Sorption Isotherms}

When any sorption system reaches a state of equilibrium, there is a defined distribution of sorbate molecules at the solid-liquid interface and also in the bulk at a particular temperature [18]. For assessing the maximum sorption capacity of a given biosorbent, the derivation of sorption isotherms is the most appropriate method. Table $\mathbf{3}$ shows various two-parameter models, namely Langmuir [19], Freundlich [20], Dubinin-Radushkevich [21], and three parameter models, namely Redlich-Peterson [20], Sips [22] and Toth [23] isotherms, that were used for fitting the data in their nonlinear form. The correlation coefficient $\left(r^{2}\right)$ was used to measure the goodness-of-fit.

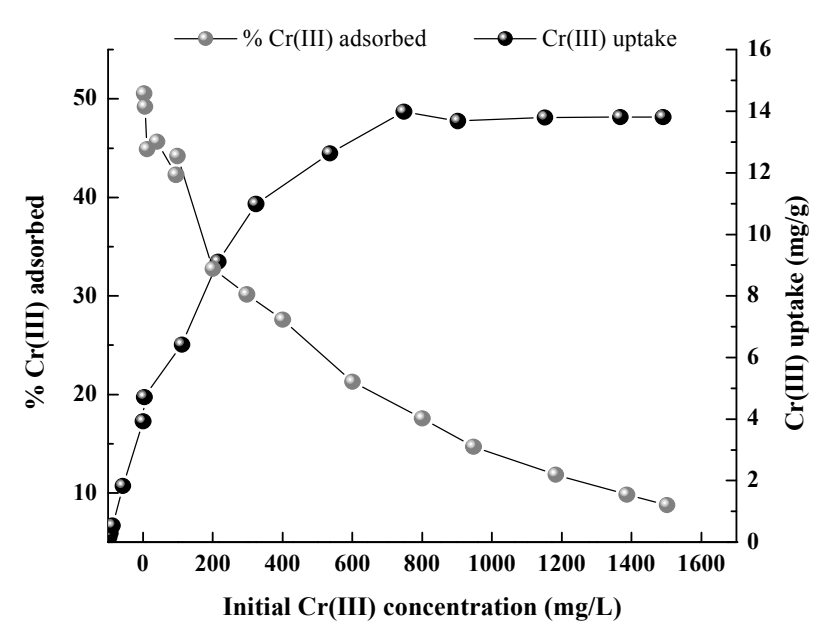

Figure 5. Effect of initial chromium concentration on equilibrium $\mathrm{Cr}$ (III) sorption capacity of $P$. nigrescens. Conditions: $\mathrm{T}=25^{\circ} \mathrm{C}$, biomass dose $=10 \mathrm{~g} / \mathrm{L}, \mathrm{pH}=4$.

Table 3. Two and three-parameter sorption isotherm models.

\begin{tabular}{|c|c|c|c|}
\hline Equation number & Isotherm model & Functional form & Parameters \\
\hline 1 & Langmuir & $q_{\mathrm{e}}=q_{\max } \frac{b C_{\mathrm{e}}}{1+b C_{\mathrm{e}}}$ & $b=$ Langmuir constant $(\mathrm{L} / \mathrm{mg})$ \\
\hline 2 & Freundlich & $q_{\mathrm{c}}=K_{\mathrm{F}} C_{\mathrm{e}}^{1 / n_{F}}$ & $\begin{array}{l}K_{\mathrm{F}}=\text { Freundlich isotherm constant }(\mathrm{L} / \mathrm{g}) \\
n_{\mathrm{F}}=\text { Freundlich exponent }\end{array}$ \\
\hline 3 & Dubinin-Radushkevich & $\begin{aligned} q_{e} & =q_{\max } \exp \left(-\beta \varepsilon^{2}\right) \\
\varepsilon & =R T \ln \left(1+\frac{1}{C_{e}}\right)\end{aligned}$ & $\begin{array}{l}\beta=\text { D-R model constant }\left(\mathrm{mol}^{2} / \mathrm{kJ}^{2}\right) \\
\varepsilon=\text { Polanyi potential }\end{array}$ \\
\hline 4 & Redlich-Peterson & $q_{\mathrm{e}}=\frac{K_{\mathrm{RP}} C_{\mathrm{e}}}{1+a_{\mathrm{RP}} C_{\mathrm{e}}^{\beta}}$ & $\begin{array}{l}K_{\mathrm{RP}}=\text { Redlich-Peterson isotherm constant }(\mathrm{L} / \mathrm{g}) \\
a_{\mathrm{RP}}=\text { Redlich-Peterson model constant }(\mathrm{L} / \mathrm{mg}) \\
\beta=\text { Redlich-Peterson model exponent }\end{array}$ \\
\hline 5 & Toth & $q_{e}=q_{\max } \frac{b_{\mathrm{T}} C_{\mathrm{e}}}{\left[1+\left(b_{\mathrm{T}} C_{\mathrm{e}}\right)^{n_{T}}\right]^{1 / n_{T}}}$ & $\begin{array}{l}b_{\mathrm{T}}=\text { Toth model constant } \\
n_{\mathrm{T}}=\text { Toth model exponent }\end{array}$ \\
\hline 6 & Sips & $q_{e}=q_{\max } \frac{\left(K_{\mathrm{s}} C_{\mathrm{e}}\right)^{\gamma}}{\left(1+\left(K_{\mathrm{S}} C_{\mathrm{c}}\right)^{\gamma}\right)}$ & $\begin{array}{l}K_{\mathrm{S}}=\text { Sips model isotherm constant }(\mathrm{L} / \mathrm{g}) \\
\gamma=\text { Sips model exponent }\end{array}$ \\
\hline
\end{tabular}

$q_{\mathrm{e}}=$ amount of solute adsorbed at equilibrium condition $(\mathrm{mg} / \mathrm{g}) ; q_{\max }=$ maximum metal uptake $(\mathrm{mg} / \mathrm{g}) ; C_{\mathrm{e}}=$ equilibrium concentration $(\mathrm{mg} / \mathrm{L}) ; R=$ gas constant $(0.0083 \mathrm{~kJ} / \mathrm{mol} \cdot \mathrm{K}) ; T=$ absolute temperature. 
The Langmuir model served to estimate the maximum metal uptake values where they could not be reached in the experiments. In general, for good sorbents, high values of $q_{\max }$ and a steep initial sorption isotherm slope as indicated by low values of $b$ are required [7]. The experimental data fit the Langmuir isotherm very well with a high value of $r^{2}=0.995$, in the given concentration range (Table 4).

The Freundlich isotherm described the adsorption on an energetically heterogeneous surface on which the adsorbed molecules are interactive [24]. Smaller value of $1 / n_{\mathrm{F}}$ implies stronger interaction between biosorbent and heavy metal while $1 / n_{\mathrm{F}}$ equal to 1 indicates linear adsorption leading to identical adsorption energies for all sites [20]. The present study results (Table 4) indicate that the Freundlich model satisfactorily describes the experimental data with the $1 / n_{\mathrm{F}}=0.42$. However, the correlation coefficients showed that the Langmuir model fitted the experimental data better than the Freundlich model $\left(r^{2}=0.969\right)$.

The experimental data were fitted to Dubinin-Radushkevich model in order to determine if the adsorption occurred by a physical or chemical process. The D-R equation is more general than Langmuir model because it does not assume a homogeneous surface or a constant sorption potential or absence of steric hindrance between sorbed and incoming particles [24]. The D-R isotherm equation contains a constant related to sorption $\beta$ $\left(\mathrm{mol}^{2} / \mathrm{kJ}^{2}\right)$ while $\varepsilon$ is the Polanyi sorption potential calculated by Equation (1)

$$
\varepsilon=R T \ln \left(1+\frac{1}{C_{\mathrm{e}}}\right)
$$

where $R$ is the gas constant $8.314 \times 10^{-3} \mathrm{~kJ} / \mathrm{mol} \mathrm{K}$, T is the temperature in Kelvin and $C_{\mathrm{e}}(\mathrm{M})$ is the metal equilibrium concentration. The Polanyi sorption approach assumes a fixed volume of sorption space close to the sorbent surface and the existence of sorption potential over these spaces [24]. The values of $\beta$ and $q_{\max }$ were calculated from the slope and intercept of the plot $\ln q_{\mathrm{e}}$ vs $\varepsilon^{2}$ (Table 4).

The mean free energy of sorption $E(\mathrm{~kJ} / \mathrm{mol})$ required to transfer one mole of ion from the infinity in the solution to the surface biomass can be determined by the following equation:

$$
E=(-2 \beta)^{-1 / 2}
$$

The sorption mean free energy calculated in the D-R model was $8.50 \mathrm{~kJ} / \mathrm{mol}$. It is a well-known fact that when the $E$ value lies between 8 and $16 \mathrm{~kJ} / \mathrm{mol}$, the adsorption process takes place by chemical ion exchange while $E<$ $8 \mathrm{~kJ} / \mathrm{mol}$ implies that the adsorption process is physical
[25]. This supports the fact that biosorption of $\mathrm{Cr}$ (III) by $P$. nigrescens may be in between a chemical and a physical process.

Redlich-Peterson is an empirical equation (Table 3), designated as the three parameter equation, which is capable to represent adsorption equilibrium over a wide concentration range [20]. Redlich and Peterson incorporated the features of the Langmuir and Freundlich isotherms into a single equation. The exponent, $\beta_{\mathrm{RP}}$, lies between 0 and 1 . There are two limiting behaviors, if $=1$, then the Langmuir will be the preferable isotherm, while if $=0$, the Freundlich isotherm will be preferred [18]. The Redlich-Peterson isotherm constants for biosorption of $\mathrm{Cr}$ (III) onto seaweed are given that in Table 4. It is worth noting that the $\beta$ value is 0.92 , i.e., the data can preferably be fitted with the Langmuir model. This is confirmed by the satisfactory fit of the data to the Langmuir model.

The Toth isotherm (Table 3) is derived from the potential theory, and it is applicable for heterogeneous adsorption [18]. This model assumes a quasi-Gaussian energy distribution, where most sites have sorption energy less than the mean value [26]. In the Toth equation is obvious that for $n_{\mathrm{T}}=1$ this isotherm reduces to the Langmuir sorption isotherm equation. The $\mathrm{Cr}$ (III) biosorption data correlate well with the Toth isotherm model and this is confirmed by high correlation coefficients (Table 4).

Table 4. Isotherm constant of two and three-parameter

\begin{tabular}{|c|c|c|}
\hline Isotherm & \multicolumn{2}{|c|}{ Parameters } \\
\hline \multirow{3}{*}{ Langmuir } & $q_{\max }(\mathrm{mg} / \mathrm{g})$ & 16.1 \\
\hline & $b(\mathrm{~L} / \mathrm{mg})$ & 0.005 \\
\hline & $r^{2}$ & 0.995 \\
\hline \multirow{3}{*}{ Freundlich } & $K_{\mathrm{F}}(\mathrm{L} / \mathrm{g})$ & 0.77 \\
\hline & $n_{\mathrm{F}}$ & 2.37 \\
\hline & $r^{2}$ & 0.969 \\
\hline \multirow{3}{*}{ D-R } & $q_{\max }(\mathrm{mg} / \mathrm{g})$ & 28.5 \\
\hline & $E(\mathrm{~kJ} / \mathrm{mol})$ & 8.50 \\
\hline & $r^{2}$ & 0.981 \\
\hline \multirow{4}{*}{ Redlich-Peterson } & $K_{\mathrm{RP}}(\mathrm{L} / \mathrm{g})$ & 0.10 \\
\hline & $a_{\mathrm{RP}}(\mathrm{L} / \mathrm{mg})$ & 0.01 \\
\hline & $\beta$ & 0.92 \\
\hline & $r^{2}$ & 0.995 \\
\hline \multirow{4}{*}{ Toth } & $q_{\max }(\mathrm{mg} / \mathrm{g})$ & 18.2 \\
\hline & $b_{\mathrm{T}}(\mathrm{L} / \mathrm{g})$ & 0.006 \\
\hline & $n_{\mathrm{T}}$ & 0.77 \\
\hline & $r^{2}$ & 0.996 \\
\hline \multirow{4}{*}{ Sips } & $q_{\max }(\mathrm{mg} / \mathrm{g})$ & 17.4 \\
\hline & $K_{\mathrm{S}}(\mathrm{L} / \mathrm{g})$ & 0.004 \\
\hline & $\gamma$ & 0.89 \\
\hline & $r^{2}$ & 0.996 \\
\hline
\end{tabular}
models for $\mathrm{Cr}$ (III) sorption onto $\boldsymbol{P}$. nigrescens.

( $\pm 95 \%$ confidence interval). 
To circumvent the problem of continuing increase in the adsorbed amount with a rising concentration as observed for Freundlich model; an expression was proposed by Sips in 1948 [22]. At low sorbate concentrations it effectively reduces to the Freundlich isotherm and thus does not obey Henry's law. At high sorbate concentrations, it predicts a monolayer sorption capacity characteristic of the Langmuir isotherm [26]. The exponent $\gamma$ value was found to be 0.89 ; so, in this case the use of Langmuir isotherm is considered more appropriate from rather than that of Freundlich, which was also confirmed by the results shown in Table 4 .

Figure 6 shows the application of two and three-parameter models in the nonlinear form.

The adsorption capacities of the adsorbents for the removal of chromium have been compared with other similar sorbents reported in literature from aqueous solutions and the values of adsorption capacities $\left(q_{\max }\right)$ have been presented in Table 5. The values are based on Langmuir sorption capacity. The experimental data of the present investigations shows that $P$. nigrescens has medium affinity for $\mathrm{Cr}$ (III) ion when compared with the reported values in literature. Therefore, it is noteworthy that seaweed has considerable potential for the removal of chromium from aqueous solutions.

\subsection{Adsorption Kinetics Study}

Sorption solid-liquid kinetics may be controlled by several independent processes, which normally act in conjunction, and involve transport phenomenon and chemical reactions [24]. Any adsorption process is normally controlled by three diffusive transport processes for the adsorbate: from bulk solution to the film surrounding the adsorbent; from the film to adsorbent surface and from

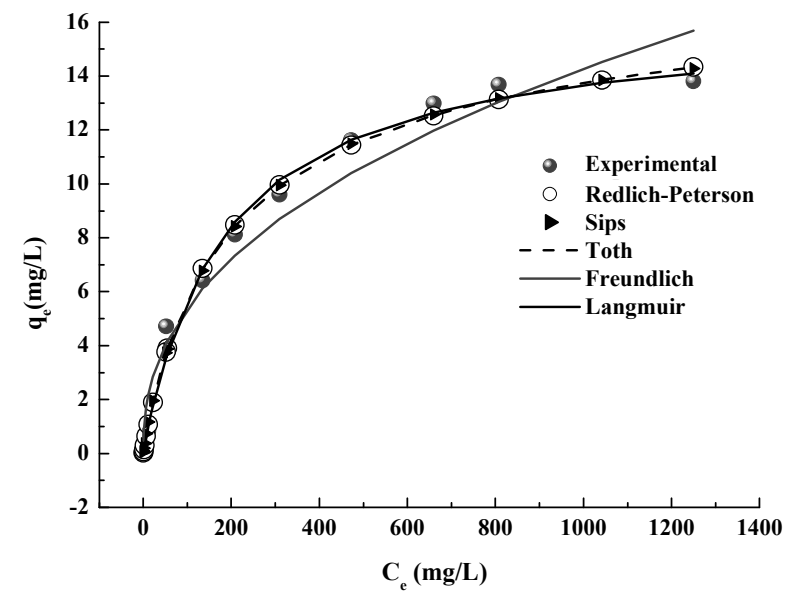

Figure 6. Application of two and three parameter models to experimental isotherm data obtained for $\mathrm{Cr}$ (III) sorption onto $P$. nigrescens.
Table 5. Comparison of biosorption capacity $\left(q_{\max }\right)$ of $P$. nigrescens for $\mathrm{Cr}$ (III) ions with that of different algae species.

\begin{tabular}{ccccc}
\hline & $\begin{array}{c}\boldsymbol{q}_{\mathbf{m a x}} \\
(\mathbf{m g} / \mathbf{g})\end{array}$ & $\mathbf{p H}$ & $\begin{array}{c}\text { Initial conc. } \\
(\mathbf{m g} / \mathbf{L})\end{array}$ & Ref. \\
\hline $\begin{array}{c}\text { Polysiphonia } \\
\text { nigrescens }\end{array}$ & 16.12 & 4.0 & $3-1200$ & This study \\
$\begin{array}{c}\text { Palmaria palmata } \\
\text { Sargassum wightii }\end{array}$ & 29.63 & 4.5 & $4.7-200$ & {$[6]$} \\
$\quad 13.00$ & 3.5 & $150-1000$ & {$[26]$} \\
Ulva lactuca & 36.91 & 4.5 & $4.7-200$ & {$[6]$} \\
$\begin{array}{c}\text { Rhizoclonium } \\
\text { hieroglyphicum }\end{array}$ & 11.81 & 4.0 & $5-500$ & {$[2]$} \\
$\begin{array}{c}\text { Spirogyra condensata } \\
\text { Spirogyra spp }\end{array}$ & 14.82 & 5.0 & $5-500$ & {$[2]$} \\
Ceramium virgatum & 28.16 & 5.0 & $20-150$ & {$[27]$} \\
$\quad$ Eckonia sp. & 20.50 & 1.5 & $10-400$ & {$[10]$} \\
\hline
\end{tabular}

the surface to the internal sites followed by binding of the metal ions onto the active sites [4]. Normally, the transport process in the bulk solution and the film diffusion through the boundary layer of sorbent are considered rapid processes, so, intra-particle diffusion or chemical binding reaction control the sorption kinetic mechanism.

In order to analyze the sorption rates of $\mathrm{Cr}$ (III) onto $P$. nigrescens biomass, four models were tested, the pseudofirst-order model, described by Lagergren in 1898 [28], the pseudo-second-order model by Ho and McKay [29], the intraparticle diffusion model by Weber-Morris [30] and Elovich model [31].

The linear form of the pseudo-first-order equation is given as follows:

$$
\ln \left(q_{\mathrm{e}}-q_{\mathrm{t}}\right)=\ln q_{\mathrm{e}}-k_{\mathrm{l}} t
$$

where $q_{\mathrm{t}}$ and $q_{\mathrm{e}}(\mathrm{mg} / \mathrm{g})$ are the amounts of the metal ions sorbed at equilibrium and $t(\mathrm{~min})$, respectively and $k_{1}$ is the rate constant of the equation $(1 / \mathrm{min})$. The sorption rate constants $\left(k_{1}\right)$ can be determined experimentally by plotting of $\ln \left(q_{\mathrm{e}}-q_{\mathrm{t}}\right)$ versus $t$. However, the calculated $q_{\mathrm{e}}$ values obtained differed from the experimental $q_{\mathrm{e}}$ values: $0.80,2.02,3.89 \mathrm{mg} / \mathrm{g}$ for initial $\mathrm{Cr}(\mathrm{III})$ concentration: 10 , 20 and $100 \mathrm{mg} / \mathrm{L}$, respectively. The $r^{2}$ are nearly 0.05 , 0.71 and 0.60 for initial $\mathrm{Cr}$ (III) concentration: 10, 20 and $100 \mathrm{mg} / \mathrm{L}$, respectively. As a consequence, the adsorption reaction could not be considered as pseudo-firstorder.

As a result of the non-applicability of pseudo-firstorder model, experimental data were also tested by pseudo-second-order kinetic model:

$$
\frac{t}{q_{\mathrm{t}}}=\left(\frac{1}{k_{2} q_{\mathrm{e}}^{2}}\right)+\left(\frac{t}{q_{\mathrm{e}}}\right)
$$


where $k_{2}(\mathrm{~g} / \mathrm{mg} \mathrm{min})$ is the rate constant of the secondorder equation, $q_{\mathrm{t}}(\mathrm{mg} / \mathrm{g})$ is the amount of biosorption at time $t(\mathrm{~min})$ and $q_{\mathrm{e}}$ is the amount of biosorption equilib$\operatorname{rium}(\mathrm{mg} / \mathrm{g})$.

In the pseudo-second-order model the rate of occupation of adsorption sites is proportional to the square of the number of unoccupied sites and the number of occupied sites is proportional to the fraction of the metal ion adsorbed [24]. This model is based on the assumption that the rate-limiting step may be the process of chemisorption involving valence forces through sharing or exchange of electrons between adsorbent and adsorbate. The pseudo-second-order biosorption rate constant $\left(k_{2}\right)$ and $q_{\mathrm{e}}$ values were determined from the slope and intercept of the plots of $t / q_{\mathrm{t}}$ against time, $t$ (Figure 7).

The values of the rate constant are presented in the Table 6. Very good fits were observed for all the $\mathrm{Cr}(\mathrm{III})$ initial concentrations ( $r^{2}$ values from 0.995 to 0.999 ) indicating that the sorption reaction followed a pseudosecond-order model. As expected the initial removal rate $\left[k_{2} q_{\mathrm{e}}^{2}(\mathrm{mg} / \mathrm{g} \mathrm{min})\right]$ was higher the for lower initial $\mathrm{Cr}(\mathrm{III})$ concentration. The existence of other processes such as intra-particle diffusion, mass transfer or ion interaction is not taken in account and the model assumes that all adsorption sites are homogeneous, and does not consider the heterogeneous nature of seaweed biomass [24].

The adsorption data may also be analyzed using the Elovich equation [31], which has the linear form:

$$
q_{\mathrm{t}}=\frac{1}{\beta} \ln (\alpha \beta)+\frac{1}{\beta} \ln t
$$

where $\alpha$ is the initial sorption rate constant $(\mathrm{mg} / \mathrm{g} \mathrm{min})$, and the parameter $\beta$ is related to the extent of surface coverage and activation energy for chemisorption $(\mathrm{g} / \mathrm{mg})$. The $\beta$ parameter values obtained was $143.6,55.9$ and $10.8 \mathrm{~g} / \mathrm{mL}$ and $\alpha$ values: $6.59 \times 10^{44}, 2.78 \times 10^{44}$ and $6.96 \times 10^{44}$ for initial $\mathrm{Cr}(\mathrm{III})$ concentration: 10,20 and $100 \mathrm{mg} / \mathrm{L}$ respectively. However, the $r^{2}$ (from 0.01 to 0.88 ) showed that the experimental data were not well fitted to the model and as a result the Elovich equation cannot be used to describe the kinetics of $\mathrm{Cr}$ (III) biosorption onto the seaweed.

In an adsorption system if intra-particle diffusion is the rate-controlling factor, uptake of the adsorbate varies with the square root of time as described by Weber and Morris in 1963 [30].

The equation on the intra-particle diffusion model is:

$$
q_{\mathrm{t}}=k_{\mathrm{d}} \mathrm{t}^{1 / 2}+C
$$

where $k_{\mathrm{d}}$ is the internal diffusion coefficient $(\mathrm{mg} / \mathrm{g}$ $\left.\min ^{1 / 2}\right), q_{\mathrm{t}}$ the amount of metal adsorbed at time $t(\mathrm{mg} / \mathrm{g})$, $t$ (min) the sorption time and $C$ can be obtained from the slope and intercept of the plot $q_{\mathrm{t}}$ versus $t^{1 / 2}$.
The intra-particle diffusion model considers the sorption as a three-stage process: the rapid adsorption, the gradual adsorption stage, where intra-particle diffusion is rate-controlled and the final equilibrium stage where intra-particle diffusion starts to slow down due to extremely low adsorbate concentrations in the solution $[24,32]$. The adsorption process can be divided into two stages for solutions with initial concentrations, $C_{\mathrm{i}}=10$, 20 and $100 \mathrm{mg} / \mathrm{L}$. However, the absence of the second linear portion was observed in solutions with $C_{\mathrm{i}}=10$ and $20 \mathrm{mg} / \mathrm{L}$, indicating that the sorption was mainly surface adsorption.

The rate constant $k_{\mathrm{d} 1}$, predicted by the intra-particle model was found to increase from 0.003 to 0.049 and $0.176 \mathrm{mg} / \mathrm{g} \mathrm{min}^{-1 / 2}$ as $C_{\mathrm{i}}$ increased from 10 to 20 and 100 $\mathrm{mg} / \mathrm{L}$, respectively.

For this first portion the correlation coefficient $\left(r^{2}\right)$ and $\mathrm{C}$ values are shows in Table 6; while for the second portion the $r^{2}, k_{\mathrm{d} 2}$ and $C$ values for solutions with initial concentrations, $C_{\mathrm{i}}=100 \mathrm{mg} / \mathrm{L}$ are $0.956,0.097$ and 2.987,

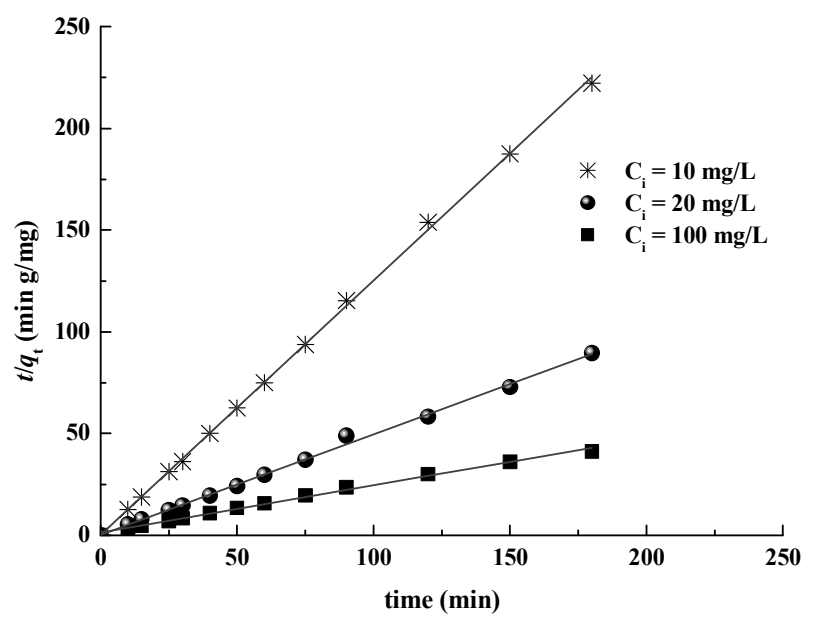

Figure 7. Plot of the pseudo-second-order equation for the sorption kinetics of $\mathrm{Cr}$ (III) on algae $P$. nigrescens at different initial chromium concentration. Conditions: $T=20^{\circ} \mathrm{C}$, biomass dosage $=10 \mathrm{~g} / \mathrm{L}, \mathrm{pH}=4$.

Table 6. Pseudo-second-order equations and the intra-particle diffusion model, calculated and experimental $q_{\mathrm{e}}$ values for different initial chromium concentrations for the $P$. nigrescens.

\begin{tabular}{cccccccc}
\hline $\begin{array}{c}\boldsymbol{C}_{\mathrm{i}} \\
(\mathbf{m g} / \mathrm{L})\end{array}$ & \multicolumn{2}{c}{$\begin{array}{c}\text { Pseudo-second-order } \\
\text { equation }\end{array}$} & \multicolumn{4}{c}{$\begin{array}{c}\text { Intra-particle diffusion } \\
\text { equation }\end{array}$} \\
\hline & $\begin{array}{c}k_{2} \\
(\mathrm{~g} / \mathrm{mg} \mathrm{min})\end{array}$ & $\begin{array}{c}q_{\mathrm{e}, \mathrm{cal}} \\
(\mathrm{mg} / \mathrm{g})\end{array}$ & $r^{2}$ & $\begin{array}{c}k_{\mathrm{d} 1} \\
\left(\mathrm{mg} / \mathrm{g} \mathrm{min} \mathrm{min}^{1 / 2}\right)\end{array}$ & $C$ & $r^{2}$ \\
\hline 10 & 7.553 & 0.78 & 0.999 & 0.003 & 0.79 & 0.292 \\
20 & 1.327 & 2.02 & 0.997 & 0.049 & 1.75 & 0.949 \\
100 & 0.039 & 4.32 & 0.995 & 0.176 & 2.57 & 0.968 \\
\hline
\end{tabular}


Table 7. Desorption efficiencies of $\mathrm{Cr}(\mathrm{III})$ on $P$. nigrescens. $[\mathrm{Cr}(\mathrm{III})]_{\mathrm{i}}=10 \mathrm{mg} / \mathrm{L}$, biomass dosage $10 \mathrm{~g} / \mathrm{L}$, pH 4.

\begin{tabular}{ccccc}
\hline $\begin{array}{c}\text { Desorbing } \\
\text { agent }\end{array}$ & $\begin{array}{c}\text { Amount of Cr(III) } \\
\text { ion adsorbed (mg/g) }\end{array}$ & $\begin{array}{c}\text { Amount of Cr(III) } \\
\text { ion desorbed (mg/g) }\end{array}$ & $\begin{array}{c}\text { Desorption efficiency } \\
\text { (\%) }\end{array}$ & $\begin{array}{c}\text { Re-adorption efficiency } \\
\text { (\%) }\end{array}$ \\
\hline $\mathrm{H}_{2} \mathrm{SO}_{4}$ & 0.37 & 0.29 & 80.5 & 10.3 \\
$\mathrm{HCl}$ & 0.35 & 0.22 & 72.3 & 25.6 \\
$\mathrm{Na}_{2} \mathrm{CO}_{3}$ & 0.39 & 0.14 & 40.1 & 71.7 \\
$\mathrm{CaCl}_{2}$ & 0.35 & 0.10 & 26.0 & 1.7 \\
\hline
\end{tabular}

respectively. Although the correlation coefficients were high, the straight lines obtained when fitting experimental data did not pass through the origin, also indicating that pore diffusion was not the only controlling step [24]. The multilinearity of simulated curves for the test data indicates that two or more steps occurred in the adsorption process. The first straight portion is attributed to the fast mass transfer of adsorbate molecule from the bulk solution to the adsorbent surface and the second linear portion to the intra-particle diffusion.

The correlation coefficients for the pseudo-secondorder kinetic model are higher than those for the intraparticle diffusion model (Table 6), suggesting a chemical reaction mechanism [24].

\subsection{Desorption Experiments}

The chromium from the seaweed needs to be removed for the safer disposal of seaweed, or the chrome-bearing seaweed should be utilized as an alternative product. Desorption could be an ideal way for the removal of chromium [1].

The possibility of desorbing chromium from biomass was examined by first sorbing $\mathrm{Cr}$ (III) onto P. nigrescens at $\mathrm{pH} 4$ and then desorbing with different desorbing agent aiming at an ion exchange process, between $\mathrm{H}^{+}, \mathrm{Na}^{+}$and $\mathrm{Ca}^{2+}$ with $\mathrm{Cr}(\mathrm{III})$ species. The percentage of chromium recovery, represented by the ratio of the amount of $\mathrm{Cr}$ released per gram of the biosorbent during desorption and the equilibrium sorption uptake, was calculated for desorption experiments lasting $2 \mathrm{~h}$. From the Table 7, it is clearly seen that desorption efficiency was $\mathrm{H}_{2} \mathrm{SO}_{4}>$ $\mathrm{HCl}>\mathrm{Na}_{2} \mathrm{CO}_{3}>\mathrm{CaCl}_{2}$. In general, the dilute acids had reasonably good recovery efficiency. In this sense, more than $80 \%$ of $\mathrm{Cr}(\mathrm{III})$ adsorbed by seaweed was released into the $\mathrm{H}_{2} \mathrm{SO}_{4}$ solution at the first cycle. Another series of experiments was conducted with the resultant biomass, which was used again for sorption and desorption experiments in one more cycle.

However, the use of these desorbing agents leads to a massive leaching of a variety of compounds from the seaweed and to the destruction of the seaweed's cellular structure confirmed by the initial weight loss of sorbent.

\section{Conclusions}

Polysiphonia nigrescens biomass was demonstrated to be an efficient material in the $\mathrm{Cr}(\mathrm{III})$ removal $(>60 \%)$ from contaminated solutions up to $100 \mathrm{mg} / \mathrm{L}$. The equilibrium sorption data fitted Langmuir, Sips and Thot isotherms. $\mathrm{Cr}(\mathrm{III})$ maximum sorption capacity was $16.11 \mathrm{mg} / \mathrm{L}$. The mean free energy of metal sorption process calculated from D-R parameter and the Polanyi potential was found to be in the range of $8-16 \mathrm{~kJ} / \mathrm{mol}$ indicating that the main mechanism governing the sorption process is most likely ion exchange. Sorption dynamics data indicated that the time required to reach sorption equilibrium was approximately $180 \mathrm{~min}$. The adsorption kinetics was rapid, showing that $40 \%$ of biosorption capacity was achieved in the first $30 \mathrm{~min}$ of contact and followed pseudo-second-order chemical reaction kinetics. Recovery studies showed relatively good yield $(80 \%)$ with dilute sulphuric acid $(0.1 \mathrm{M})$ being the best desorbing agent. The FTIR analysis indicates that the involvement of hydroxyl, carbonyl, carboxyl and sulfonic groups in the binding of chromium metal ions. The SEM-EDX analysis suggests ion-exchange process as alkaline ions were simultaneously exchanged for chromium metal ions. XAS analysis confirms that metal ion interaction with seaweed.

Results obtained from this study showed that $P$. nigrescens can be a good adsorbent for the removal of $\mathrm{Cr}(\mathrm{III})$ from aqueous solutions in a static batch system.

\section{Acknowledgements}

We thank the National Research Council of Argentina (CONICET) PIP 0075, National University of Rosario (UNR) PIP BIO145 and Secretary of State of Science, Technology and Innovation of Santa Fe, Project 2.1 (2160-10) for financial support. L.F. Sala and M. Harada thank the Photon Factory Advisory Committee (PAC) at the High Energy Accelerator Research Organization (KEK) for approval to perform XAFS measurements (Proposal 
No. 2009G184). Blanes thanks National Academy of Exact, Physic and Natural Sciences (ANCEFN) of Argentina for grating a $\mathrm{PhD}$ fellowship.

\section{References}

[1] R. Garcia-Reyes, J. Rangel-Mendez and M. Alfaro-De la Torre, "Chromium (III) Uptake by Agro-Waste Biosor-Bents: Chemical Characterization, Sorption-Desorption Studies, and Mechanism," Journal of Hazardous Materials, Vol. 170, No. 2-3, 2009, pp. 845-854. doi:10.1016/j.jhazmat.2009.05.046

[2] D. Onyancha, W. Mavura, J. Ngila, P. Ongomab and J. Chacha, "Studies of Chromium Removal from Tannery Waste-Waters by Algae Biosorbents, Spirogyra condensata and Rhizoclonium hieroglyphicum," Journal of Hazardous Materials, Vol. 158, No. 2-3, 2008, pp. 605614. doi:10.1016/j.jhazmat.2008.02.043

[3] D. Park, Y. Yun, J. Jo and J. Park, "Biosorption Process for Treatment of Electroplating Wastewater Containing $\mathrm{Cr}(\mathrm{VI})$ : Laboratory-Scale Feasibility Test," Industrial \& Engineering Chemistry Research, Vol. 45, No. 14, 2006, pp. 5059-5065. doi:10.1021/ie060002d

[4] S. Bellú, L. Sala, J. González, S. García, M. Frascaroli, P. Blanes, J. García, J. Salas Peregrin, A. Atria, J. Ferrón, M. Harada, C. Cong and Y. Niwa, "Thermodynamic and Dynamic of Chromium Biosorption by Pectic and Lignocellulocic Biowastes," Journal of Water Resource and Protection, Vol. 2, No. 10, 2010, pp. 888-897. doi:10.4236/jwarp.2010.210106

[5] S. Baral, N. Das, G. Chaudhury and S. Das, "A Preliminary Study on the Adsorptive Removal of Cr(VI) Using Seaweed, Hydrilla verticillata," Journal of Hazardous Materials, Vol. 171, No. 1-3, 2009, pp. 358-369. doi:10.1016/j.jhazmat.2009.06.011

[6] V. Murphy, H. Hughes and P. McLoughlin, "Comparative Study of Chromium Biosorption by Red, Green and Brown Seaweed Biomass," Chemosphere, Vol. 70, No. 6, 2008, pp. 1128-1134. doi:10.1016/j.chemosphere.2007.08.015

[7] B. Volesky, "Sorption and Biosorption," BV Sorbex, Inc., Montreal, 2003.

[8] T. A. Davis, B. Volesky and A. Mucci, "A Review of Biochemistry of Heavy Metal Biosorption by Brown Algae," Water Research, Vol. 37, No. 18, 2003, pp. 43114330. doi:10.1016/S0043-1354(03)00293-8

[9] P. Sheng, Y. Ting, J. Chen and L. Hong, "Sorption of Lead, Copper, Cadmium, Zinc, and Nickel by Marine Algal Biomass: Characterization of Biosorptive Capacity and Investigation of Mechanisms," Journal of Colloid and Interface Science, Vol. 275, No. 1, 2004, pp. 131-141. doi:10.1016/j.jcis.2004.01.036

[10] A. Sari and M. Tuzen, "Biosorption of Total Chromium from Aqueous Solution by Red Algae (Ceramium virgatum): Equilibrium, Kinetic and Thermodynamic Studies," Journal of Hazardous Materials, Vol. 160, No. 2-3, 2008, pp. 349-355. doi:10.1016/j.jhazmat.2008.03.005

[11] H. Prado, M. Ciancia and M. Matulewicz, "Agarans from the Red Seaweed Polysiphonia nigrescens (Rhodomelaceae, Ceramiales)," Carbohydrate Research, Vol. 343, No. 4, 2008, pp. 711-718. doi:10.1016/j.carres.2007.12.024

[12] L. Yang and J. Chen, "Biosorption of Hexavalent Chromium onto Raw and Chemically Modified Sargassum sp," Bioresource Technology, Vol. 99, No. 2, 2008, pp. 297-307. doi:10.1016/i.biortech.2006.12.021

[13] D. Lazar, B. Ribár, V. Divjakovic and C. Mészáros, "Structure of Hexaaquachromium (III) Nitrate Trihydrate," Acta Crystallographica Section C, Vol. 47, 1991, pp. 1060-1062. doi:10.1107/S0108270190012628

[14] D. Park and J. Park, "XAS and XPS Studies on Chromium-Binding Groups of Biomaterial during $\mathrm{Cr}(\mathrm{VI})$ Biosorption," Journal of Colloid and Interface Science, Vol. 317, No. 1, 2008, pp. 54-61. doi:10.1016/j.jcis.2007.09.049

[15] Y. Yun, D. Park, J. Park and B. Volesky, "Biosorption of Trivalent Chromium on the Brown Seaweed Biomass," Environ Science Technollogy, Vol. 35, No. 21, 2001, pp. 4353-4358. doi:10.1021/es010866k

[16] U. Garg, M. Kaur, V. Garg and D. Sud, "Removal of Hexavalent Chromium from Aqueous Solution by Agricultural Waste Biomass," Journal of Hazardous Materials, Vol. 140, No. 1-2, 2007, pp. 60-68. doi:10.1016/j.jhazmat.2006.06.056

[17] S. Bellú, S. García, J. González, A. Atria, L. Sala and S. Signorella, "Removal of Chromium(VI) and Chromium (III) from Aqueous Solution by Grain-Less Stalk of Corn," Separation Science and Technology, Vol. 43, No. 11-12, 2008, pp. 1- 21.

[18] M. Hubbe, S. Hasan and J. Ducoste, "Cellulosic Substrates for Removal of Pollutants from Aqueous Systems: A Review. 1. Metals," BioResources, Vol. 6, No. 2, 2011, pp. 2161-2287.

[19] I. Langmuir, "The Adsorption of Gases on Plane Surface of Glass, Mica and Platinum," Journal of the American Che- mical Society, Vol. 40, No. 9, 1918, pp. 1361-1403. doi:10.1021/ja02242a004

[20] J. Febrianto, A. Kosasih, J. Sunarso, Y. Ju, N. Indraswati and S. Ismadji, "Equilibrium and Kinetic Studies in Adsorption of Heavy Metals Using Biosorbent: A Summary of Recent Studies," Journal of Hazardous Materials, Vol. 162, No. 2-3, 2009, pp. 616-645. doi:10.1016/j.jhazmat.2008.06.042

[21] M. Dubinin, "The Potential Theory of Adsorption of Gases and Vapors for Adsorbents with Energetically Non-Uniform Surface," Chemical Reviews, Vol. 60, No. 2, 1960, pp. 235-266. doi:10.1021/cr60204a006

[22] R. Sips, "On the Structure of a Catalyst Surface," Journal of Chemical Physics, Vol. 16, No. 490, 1948, pp. 490495. doi:10.1063/1.1746922

[23] S. Basha, Z. Murthy and B. Jha, "Sorption of $\mathrm{Hg}$ (II) from Aqueous Solutions onto Carica papaya: Application of Isotherms," Industrial \& Engineering Chemistry Research, 
Vol. 47, No. 3, 2008, pp. 980-986. doi:10.1021/ie0712100

[24] P. Miretzky, C. Muñoz and A. Carrillo-Chavez, "Cd(II) Removal from Aqueous Solution by Eleocharis acicularis Biomass, Equilibrium and Kinetic Studies," Bioresource Technology, Vol. 101, No. 8, 2010, pp. 2637-2642. doi:10.1016/j.biortech.2009.10.067

[25] B. Kiran and A. Kaushik, "Chromium Binding Capacity of Lyngbya putealis Exopolysaccharides," Biochemical Engineering Journal, Vol. 38, No. 1, 2008, pp. 47-54. doi:10.1016/j.bej.2007.06.007

[26] Y. Ho, J. Porter and G. McKay, "Equilibrium Isotherm Studies for the Sorption of Divalent Metal Ions onto Peat: Copper, Nickel and Lead Single Component Systems," Water Air \& Soil Pollution, Vol. 141, No. 1-4, 2002, pp. 1-33. doi:10.1023/A:1021304828010

[27] N. Bishnoi, R. Kumar, S. Kumar and S. Rani, "BioSorption of Cr(III) from Aqueous Solution Using Algal Biomass Spirogyra spp," Journal of Hazardous Materials, Vol. 145, No. 1-2, 2007, pp. 142-147. doi:10.1016/j.jhazmat.2006.10.093

[28] S. Lagergren, "About the Theory of So-Called Adsorp- tion of Soluble Substances, Zur Theorie der Soge-Nannten Adsorption Gelöster Stoffe," Kungliga Svenska Vetenskapsakademiens, Handlingar, Band, Vol. 24, 1898, pp. 1-39.

[29] Y. Ho, D. Wase and C. Forster, "Kinetic Studies of Competitive Heavy Metal Adsorption by Sphagnum Moss Peat," Environmental Technology, Vol. 17, No. 1, 1996, pp. 71-77. doi:10.1080/09593331708616362

[30] W. Weber Jr. and J. Morris, "Kinetics of Adsorption on Carbon from Solution," Journal of the Sanitary Engineering Division ASCE, Vol. 89, No. 2, 1963, pp. 31-59.

[31] Y. Ho and G. McKay, "Application of Kinetic Models to the Sorption of Copper(II) on to Peat," Adsorption Science \& Technology, Vol. 20, No. 8, 2002, pp. 795-817. doi:10.1260/026361702321104282

[32] D. Gialamouidis, M. Mitrakas and M. LiakopoulouKyriakides, "Equilibrium, Thermodynamic and Kinetic Studies on Biosorption of Mn(II) from Aqueous Solution by Pseudomonas sp., Staphylococcus xylosus and Blakeslea trispora Cells," Journal of Hazardous Materials, Vol. 182, No. 1-3, 2010, pp. 672-680. doi:10.1016/j.jhazmat.2010.06.084 